\title{
Spacing between Soybean Rows
}

\section{Luiz Claudio Garcia*, Ivo Frare, Thiago Inagaki, Pedro Henrique Weirich Neto, Marcos Martins, Maghnom Henrique Melo, Leandro Nadolny, Marcos Kruppa Rogenski, Newton Seifert Filho, Ezequiel Barbosa de Oliveira}

Department of Soil Science and Agricultural Engineering, State University of Ponta Grossa, Ponta Grossa, Brazil

Email: *1cgarcia@uepg.br

How to cite this paper: Garcia, L.C., Frare, I., Inagaki, T., Neto, P.H.W., Martins, M., Melo, M.H., Nadolny, L., Rogenski, M.K., Filho, N.S. and de Oliveira, E.B. (2018) Spacing between Soybean Rows. American Journal of Plant Sciences, 9, 711-721. https://doi.org/10.4236/ajps.2018.94056

Received: January 8, 2018

Accepted: March 16, 2018

Published: March 19, 2018

Copyright (c) 2018 by authors and Scientific Research Publishing Inc. This work is licensed under the Creative Commons Attribution International License (CC BY 4.0).

http://creativecommons.org/licenses/by/4.0/

\begin{abstract}
The soybean crop has great economical importance in Brazil and in the world. In order to make the crop production profitable, several factors must be considered. The objective of this study was to evaluate the impact of spacing between soybean crop rows (Glycine max). The experiment was installed in the Mutuca farm (Arapoti-PR, southern Brazil), in the crop seasons of 2012/2013 (four seeding seasons) and 2013/2014 (two seeding seasons), in a completely randomized blocks design. We used four treatments and six replicates. The treatments were the spacing between rows as follow: $0.25,0.50,0.75$ and 1.00 $\mathrm{m}$. The variables evaluated were: initial and final plant population, plant height, number of internodes, viable internodes, pods per plant, grains per pod, mass of thousand grains and crop productivity. We concluded that the reduction of the spacing between rows significantly increased, in most part of the crop seasons, the number of pods per plants and the crop productivity.
\end{abstract}

\section{Keywords}

Productivity Components, Glycine max, No-Till System

\section{Introduction}

The soybean agribusiness (Glycine max) has become one of the main productive chains of the Brazilian agricultural structure. In the 2013/2014 crop season, the crop production reached more than 87 million tons, on more than 30 million of hectares; with average crop yield of $2900 \mathrm{~kg} \cdot \mathrm{ha}^{-1}$. The grain, oil and bran segments earned US $\$ 31$ billion, which means $12.8 \%$ of all Brazilian external selling and $31 \%$ of Brazilian agribusiness exports [1].

Soybean yield is the result of management techniques in the selection of cultivar, seeding season, population, fertilization and pest control. The spacing between sowing lines can influence intercepted luminosity, weed occurrence, diseases, pesticide application technology, pest incidence and plant architecture [2] 


\section{[3] [4] [5] [6].}

The alteration of the row spacing of the soybean is possible due to the high phenotypic plasticity of the crop, which consists in the ability of the plant to change its morphology and yield components in order to adapt to the condition imposed by the spatial arrangement. This compensatory capacity may induce low density soybean plants to emit larger numbers of branches and form more robust stems, increasing the number of pods per plant. Thus, the smaller amount of individuals per area can be counterbalanced by the higher production per unit [7]. Working in the southern United States with soybean cultivars at row spacing of 0.38 and $0.76 \mathrm{~m}$, and interacting three maturation groups in the harvests from 2005 to 2007, Thompson et al. [8] concluded that the spacing of $0.38 \mathrm{~m}$ presented the best yields in all experimental arrangements.

In order to determine the ideal spacing between soybean rows in hot sub-humid tropical conditions in southwestern Ethiopia, Worku and Astatkie [9] studied distances of $0.20,0.25,0.30,0.35,0.40,0.45,0.50,0.55$ and $0.60 \mathrm{~m}$. When interpolating data from two cultivars sown in 2005 and 2007, the results indicated that the spacing of $0.40 \mathrm{~m}$ between rows of plants can be used to obtain high yields.

In crop seasons from 2006 to 2008, Zhou et al. [10] examined the spacing between soybean rows of $0.18,0.27,0.36,0.45$ and $0.54 \mathrm{~m}$. The authors pointed out that spacing between rows of soybean $\leq 0.27 \mathrm{~m}$ is a highly suitable cropping system for the plains of northern China.

Testing the spacing between soybean rows of $0.19,0.45$ and $0.90 \mathrm{~m}$ at two densities in the 2012 and 2013 (Arkansas-USA) crops, Bell et al. [11] argue that the best yields reached $0.45 \mathrm{~m}$ row spacing, in the two crop seasons.

As in all soybean production areas, in Brazil we have been observing an important role of spacing between rows on crop yield. To investigate a soybean agronomic performance in the 2011/12 and 2012/13 crop seasons in Ponta Porã (MT-Brazil), Rosa et al. [12] have applied NPK fertilizer rates in row spacing of $0.35,0.45,0.50,0.60$ and $0.70 \mathrm{~m}$. With the increase of the spacing, a higher final population and height of the plant were obtained. Increasing spacing reduced the insertion height of the first pod, number of branches per plant, pods per plant, grains per pod, grains per plant and productivity. Thus, the authors emphasized the smaller spacing as an ideal.

In the region of Cascavel-PR, southern Brazil, Silva et al. [13] also evaluated the behavior of two cultivars, in the 2013/14 crop, with four densities and two spacing $(0.25$ and $0.50 \mathrm{~m})$. The authors assure that the spacing of $0.25 \mathrm{~m}$ presented the best yields in most part of the interactions between treatments.

Thus, this study aimed to assess the impact of row spacing in soybean (Glycine max); In the Mutuca farm (Arapoti-PR, Brazil), in the 2012/13 (four seeding seasons) and 2013/14 (two seeding seasons) seasons.

\section{Material and Methods}

The experiments were carried out at Mutuca farm, municipality of Arapoti-PR 
(southern Brazil), latitude $24^{\circ} 27^{\prime} 31^{\prime \prime} \mathrm{S}$, longitude $50^{\circ} 10^{\prime} 42^{\prime \prime} \mathrm{W}$ and $970 \mathrm{~m}$ altitude, in Eutrophic Red Latosol soil, in no-till system. The farm is reference in Brazil due its high yield levels. The climate of the region is classified as $\mathrm{Cfb}$, with agrometeorological conditions that favored the crops during the period of the experiments. All the crop practices followed the recommendations of the agronomist responsible for the area.

The experimental design was performed in randomized blocks with four treatments and six replicates. Treatments comprised of row spacing of $0.25 ; 0.50$; 0.75 and $1.00 \mathrm{~m}$. The field plots had an evaluation area of $20 \mathrm{~m}^{2}$.

BMX APOLO RR $\mathrm{R}^{\oplus}$ soybean cultivar was used; Presenting a super-early cycle, with maturation group 5.5, indeterminate growth habit. In the 2012/13 crop season, the four sowing times occurred on the days: $02 / 10 / 2012,21 / 10 / 2012$, $14 / 11 / 2012$ and 05/12/2012; with 225,000 seeds $\mathrm{ha}^{-1}$. In the 2013/14 crop season, soybean crop was sown on November 20 and December 12, 2013; with 360,000 seeds $\mathrm{ha}^{-1}$. The difference between the populations along the harvests was determined by technical decision, mainly based on the soil fertility of the plot in which the experiment was installed and agro climatic prediction. The chemical attributes of the soil of the experimental area data is presented on Table 1.

For the seeds treatment, we applied the inoculant Nitral Urbana ${ }^{\oplus}$ (1, 0 liquid dose and another turfed per hectare), $0.3 \mathrm{~L} 100 \mathrm{~kg} \mathrm{seeds}^{-1}$ of VitavaxThiran ${ }^{\oplus}(0.2$ $\mathrm{kg} \cdot \mathrm{L}^{-1}$ of Carboxine $+0.2 \mathrm{~kg} \cdot \mathrm{L}^{-1}$ of Tiram) and $0.06 \mathrm{~L}$ of SeedDryCoMo ${ }^{\bullet}$. The soil water content at the depth of $0.05 \mathrm{~m}$ was $30 \%$. During the seeding, there was $5.6 \mathrm{Mg} \cdot \mathrm{ha}^{-1}$ of crop residue from the previous crop (Wheat-Triticum aestivum) of the crop season 2012/13 and 6.8 Mg.ha ${ }^{-1}$ of crop residues from the 2013/2014 crop season, being chemically managed for seven days before the soybean seeding. There was no fertilization during the seeding process, since under no-till system, the responsible agronomist dilutes the fertilization among the rotated crops.

The seeder used was SSM-27 Semeato ${ }^{\circ}$; seeding lines were equipped with a smooth cutting disc of $0.36 \mathrm{~m}$ of diameter; "machete" type fertilizer furrows with $0.025 \mathrm{~m}$ wide tips and 20 attack angle (guillotine); and opening mechanism of the seed furrow with mismatched double disk diameter of $0.33 \mathrm{~m}$. The sowing speed was $5 \mathrm{~km} \cdot \mathrm{h}^{-1}$. The machine was adjusted for providing seeding depth of $0.04 \mathrm{~m}$.

The sowing disc used was a 6.5 sieve with 86 holes. Thus, the tangential velocities reached by the horizontal perforated disc at spacing of $0.25,0.50,0.75$ and

Table 1. The chemical attributes of the soil, de 0.0 a $0.1 \mathrm{~m}$, Mutuca farm (Arapoti-PR, Brazil).

\begin{tabular}{|c|c|c|c|c|c|c|c|c|c|c|c|}
\hline \multirow{2}{*}{$\begin{array}{l}\text { Crop } \\
\text { Season }\end{array}$} & \multirow{2}{*}{$\mathrm{pH}$} & $\mathrm{H}+\mathrm{Al}$ & $\mathrm{Al}$ & $\mathrm{Ca}$ & $\mathrm{Mg}$ & K & CTC & \multirow{2}{*}{$\begin{array}{c}\mathrm{P}(\text { Mehlich }) \\
\mathrm{mg} \cdot \mathrm{dm}^{-3}\end{array}$} & \multirow{2}{*}{$\frac{\mathrm{MO}^{*}}{\mathrm{~g} \cdot \mathrm{dm}^{-3}}$} & \multirow{2}{*}{$\begin{array}{l}\mathrm{V} \\
\%\end{array}$} & \multirow{2}{*}{$\begin{array}{l}\mathrm{Al} \\
\%\end{array}$} \\
\hline & & \multicolumn{6}{|c|}{ mmolc $\cdot \mathrm{dm}^{-3}$} & & & & \\
\hline $2012 / 13$ & 5.6 & 44 & 3.0 & 28 & 15 & 3.5 & 78 & 11.8 & 2.2 & 52 & 0.6 \\
\hline $2013 / 14$ & 6.2 & 33 & 0.0 & 36 & 17 & 4.1 & 92 & 15.4 & 4.1 & 63 & 0.0 \\
\hline
\end{tabular}


1.00 meter were respectively $0.05,0.11,0.16$ and $0.21 \mathrm{~m} \cdot \mathrm{s}^{-1}$.

The variables analyzed were: initial population (20 days after emergence), final population, plant height, number of viable internodes and internodes, pods per plant, grains per pod, one thousand grain mass and productivity. The evaluations were performed manually in the $20 \mathrm{~m}^{2}$ of each plot. The initial population was evaluated 15 days after the emergency. The variables plant height, final population, number of internodes, viable internodes, pods per plant and grains per pod were performed at phenological stage R7. For height of plants a ruler graduated in centimeters with $1.5 \mathrm{~m}$ of height was used.

The harvests occurred in the crop season of $2012 / 13$ on $08 / 02,20 / 02,10 / 3$ and $03 / 29 / 2013$; and in the season $2013 / 14$ on days $14 / 3$ and $04 / 04 / 2014$. The calculation of the mass of a thousand grains and the productivity occurred with $1.0 \%$ of impurities and with moisture corrected to $14.0 \%$. The humidity was verified with the G800 Gehaka ${ }^{\circledast}$ equipment. The mass of 1000 grains was defined by means of a 500 Diamond $^{\oplus}$ digital scale, with a capacity of 0.1 to $500 \mathrm{~g}$. The productivity measurement was carried out using a DP50 Ramuza ${ }^{\circledast}$ digital scale, with a capacity of $50 \mathrm{~kg}$.

The values recorded were submitted to the Hartley tests, to verify the homoscedasticity of the variances, and Shapiro-Wilk to examine the normality of the data. The measured variables were submitted to $\mathrm{F}$ tests and polynomial regression, with a confidence level greater than $95 \%$ of significance.

\section{Results and Discussion}

The Hartley test pointed to the homoscedasticity of the variances and Shapiro-Wilk confirmed the normality of the data, for all variables studied. Therefore, there was no need to transform the values for the analysis of variance.

Regarding the first crop season of the 2012/13, on October 2, 2012, there were only significant differences for blocks in the pods per plant variable. The analysis of variance was not significant for the variables: initial population (average of 215,043 plants $\mathrm{ha}^{-1}$ ), final population (average of 208,347 plants ha ${ }^{-1}$ ), plant height (mean $0.76 \mathrm{~m}$ ), number of internodes (mean of 16) and viable internodes (mean of 13), grains per pod (mean of 2.48) and mass of one thousand grains (average of $0.21 \mathrm{~kg}$ ). The polynomial regression highlighted significant differences for the variables: pods per plant and productivity, with a linear adjustment (Figure 1).

Analyzing data from the second crop season of 2012/13, on October 21, 2012, there were significant differences for blocks for the variables height of plants, pods per plant and total internodes. The analysis of variance was not significant for the variables: initial population (average of 216,421 plants ha ${ }^{-1}$ ), final population (average of 209,381 plants ha ${ }^{-1}$ ), plant height (mean of $0.91 \mathrm{~m}$ ), number of internodes (mean of 15) and viable internodes (mean of 12), pods per plant (average of 48) and mass of one thousand grains (average of $0.19 \mathrm{~kg}$ ). The polynomial regression highlighted significant differences for the variables: grain per 

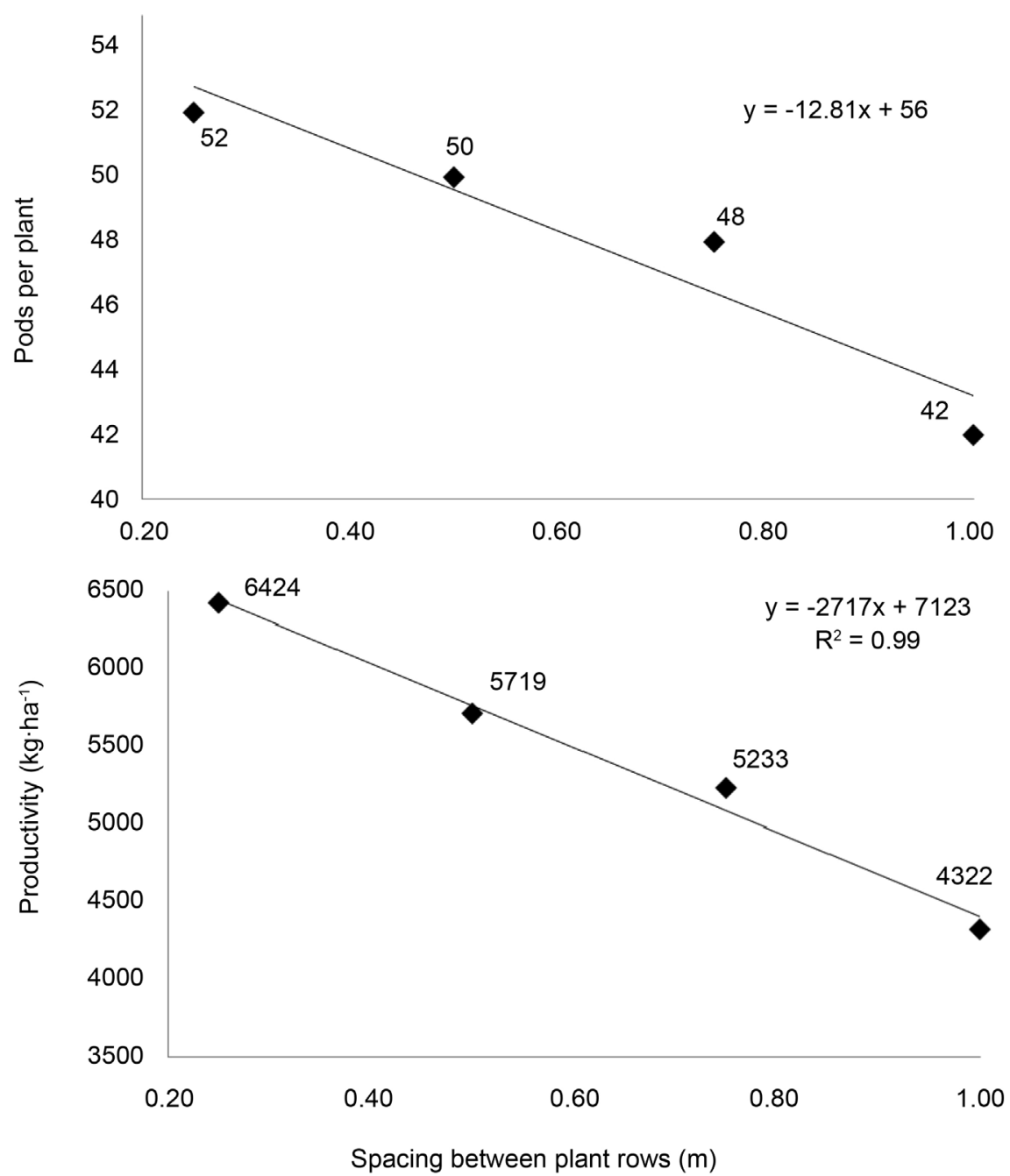

Figure 1. Components of soybean yield (Glycine max), cultivar BMX Apollo RR ${ }^{\circledast}$, seeded with different row spacings on 10/02/2012, Mutuca Farm (Arapoti-PR, Brazil).

pod and productivity, with linear adjustment (Figure 2).

Studying data from the third crop season of 2012/13, on November 14, 2012, there were significant differences for blocks for the final population variable. The analysis of variance was not significant for the variables: initial population (average of 212,213 plants ha ${ }^{-1}$ ), final population (average of 198,033 plants ha ${ }^{-1}$ ), number of internodes (average of 16) and viable internodes, grains per pod (average of 2.70) and one thousand grain mass (average of $0.20 \mathrm{~kg}$ ). The polynomial regression highlighted significant differences for the variables: plant height, pods per plant and productivity, with linear regression (Figure 3).

The values of the fourth crop season of 2012/13, on December 5, 2012, point out that there were no significant differences for blocks for all the variables under study, denoting the homogeneous conditions of the experiment. The polynomial regression highlighted significant differences for the variables: pods per plant and productivity, with linear adjustment (Figure 4).

The values of the first crop season of 2013/14, on November 20, 2013, point 

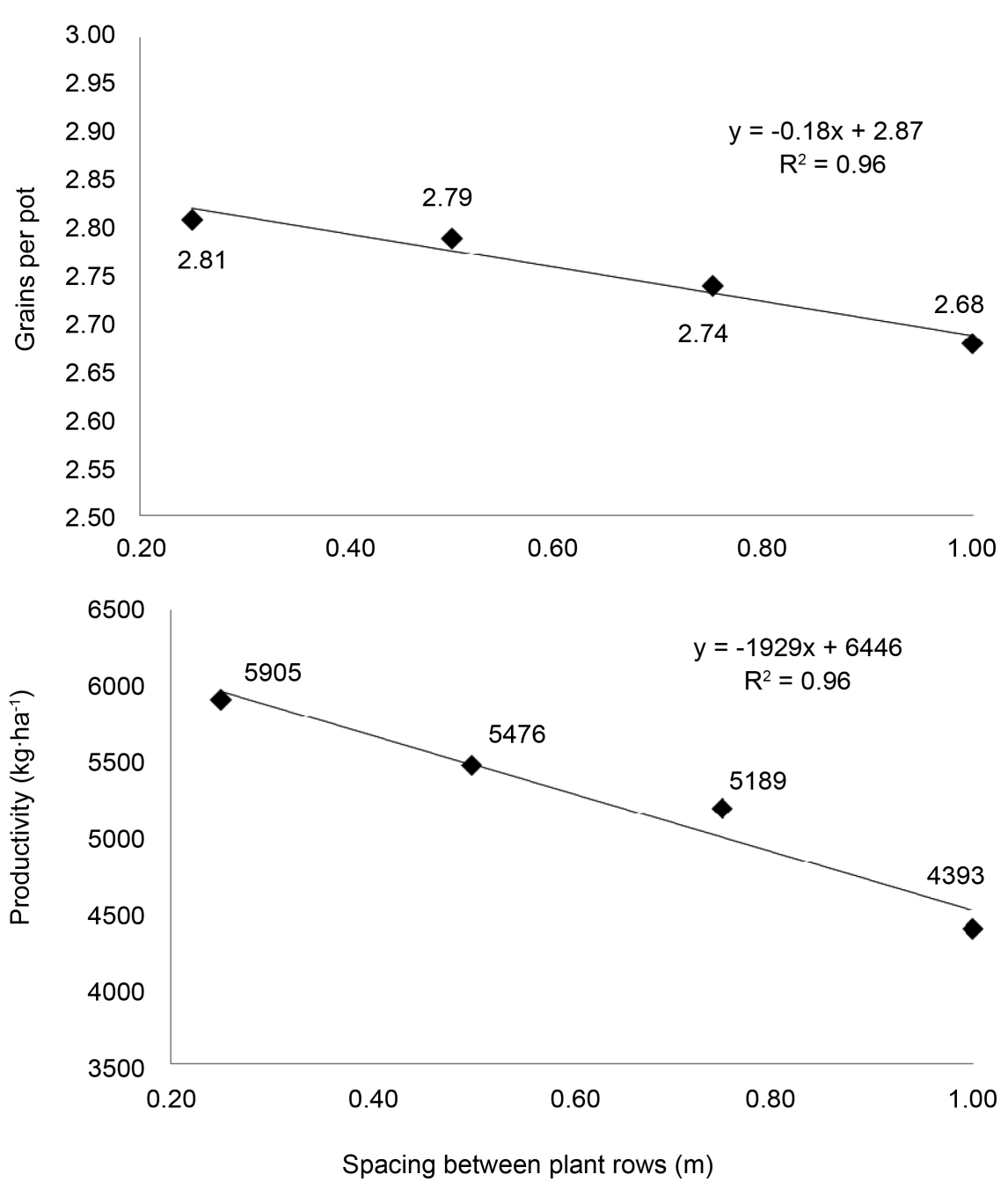

Figure 2. Components of soybean yield (Glycine max), cultivar BMX Apollo RR ${ }^{\circledR}$, seeded with different row spacing on 10/21/2012, Mutuca Farm (Arapoti-PR, Brazil).

out that there were significant differences for blocks for the variables: initial population, height of plants and grains per pods. The analysis of variance was not significant for the variables: initial population (average of 353,750 plants $\mathrm{ha}^{-1}$ ), final population (average of 291,250 plants ha ${ }^{-1}$ ), plant height (average of $0.93 \mathrm{~m}$ ), number of internodes (mean of 16) and viable internodes (mean of 13), grains per pod (average of 2.50 ) and mass of one thousand grains $(0.17 \mathrm{~kg})$. The polynomial regression highlighted significant differences for the variables: pods per plant and productivity, with better representation of the data by a straight line (Figure 5).

The values of the second crop season of 2013/14, on December 12, 2013, pointed out that there were significant differences for blocks only for the variable mass of a thousand grains, with a confidence level higher than $95 \%$ of probability. The analysis of variance was not significant for the variables: initial population (mean of 354,772 plants $\mathrm{ha}^{-1}$ ), final population (average of 288,333 plants $\mathrm{ha}^{-1}$ ), plant height (mean of $0.94 \mathrm{~m}$ ), number of internodes (average of 17) and 

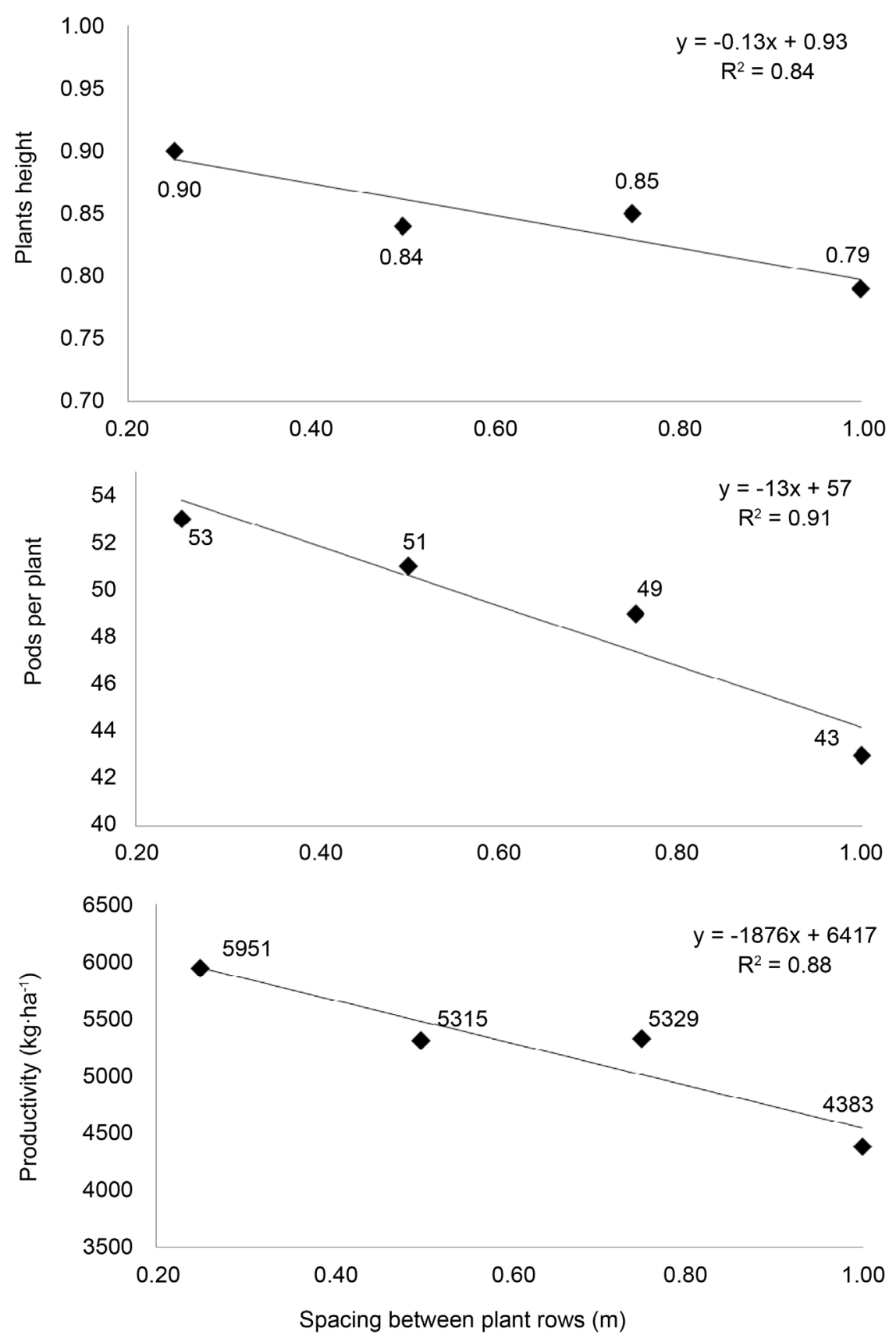

Figure 3. Plants height and yield components in the soybean crop (Glycine max), cultivar BMX Apollo $\mathrm{RR}^{\circledR}$, seeded with different row spacing on 11/14/2012, Mutuca Farm (Arapoti-PR, Brazil).

viable internodes (average of 15), pods per plant (average of 34) and grains per pod (average of 2.50). The polynomial regression highlighted significant differences for the variables: thousand grains mass and productivity, with better representation of the data by a straight line (Figure 6).

Experiment productivity in the six crops averaged $5104 \mathrm{~kg} \cdot \mathrm{ha}^{-1}, 76 \%$ higher than the national average of $2900 \mathrm{~kg} \cdot \mathrm{ha}^{-1}$ [1]. The results indicate the high technique of soybean cultivation in no-tillage, conducted at Mutuca farm. Thus, the 


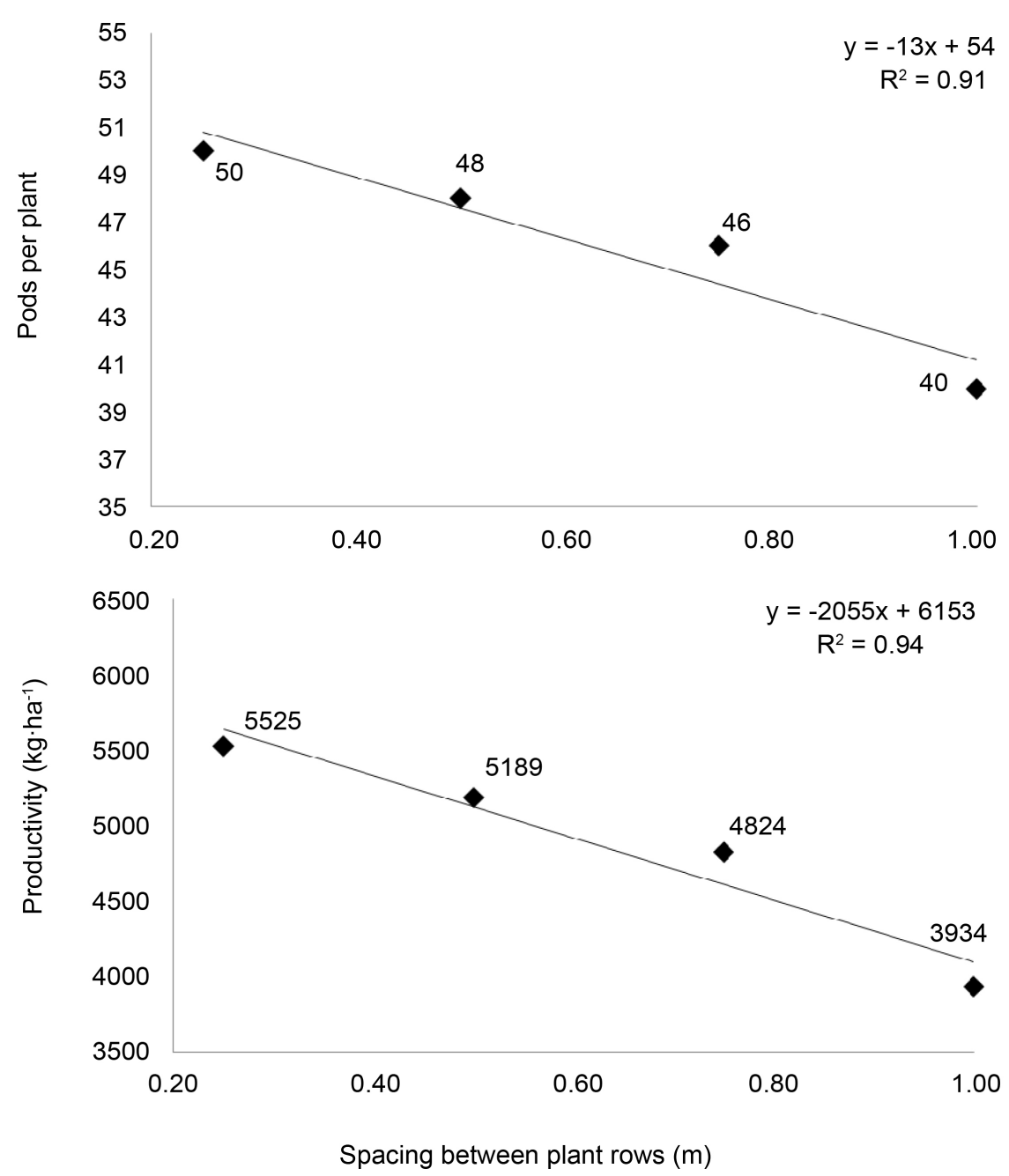

Figure 4. Components of soybean yield (Glycine max), cultivar BMX Apollo RR ${ }^{\circledast}$, seeded with different row spacing on 12/05/2012, Mutuca farm (Arapoti-PR, Brazil).

high phenotypic plasticity of the crop is confirmed [6], highlighting the highest number of pods per plant for the most equidistant distribution among plants; resulting in higher productivity. The importance of the special arrangement of plants corroborates with Weirich Neto et al. [2], Aulakh and Jhala [3], Balbinot Jr et al. [4], Hartman et al. [5] and Koester et al. [6].

The results confirm the studies of Thompson et al. [8], who worked in the southern United States with soybean cultivars at row spacing of 0.38 and $0.76 \mathrm{~m}$, interacting three maturation groups in the 2005 to 2007 harvests. The authors also concluded that the smaller row spacing presented the best yields in all experimental arrangements.

However, the values obtained in this experiment contrast with the conclusions of Worku and Astatkie [9]. When interpolating data from two cultivars sown in the 2005 and 2207 crops in warm sub-humid tropical conditions in southwestern Ethiopia, the authors suggest that a spacing of $0.40 \mathrm{~m}$ between rows of plants can be used to achieve high yields. In the temperate climate conditions of southern 


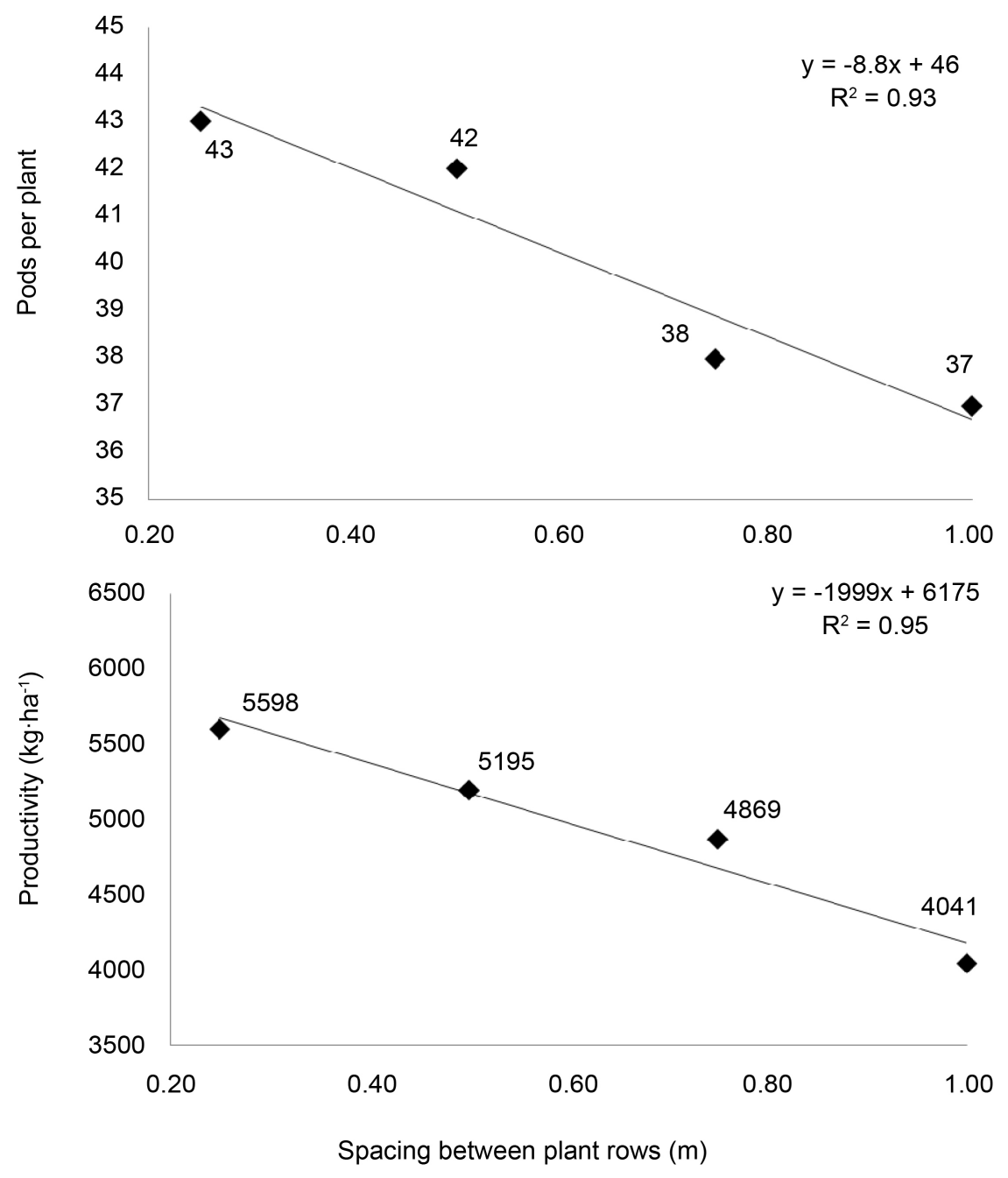

Figure 5. Components of soybean yield (Glycine max), cultivar BMX Apollo RR ${ }^{\circledR}$, seeded with different row spacing on 11/20/2013, Mutuca farm (Arapoti-PR, Brazil).

Brazil, the spacing of $0.25 \mathrm{~m}$ between rows of soybean plants was highlighted.

In harvests from 2006 to 2008, Zhou et al. [10], point out that row spacing of soybean $\leq 0.27 \mathrm{~m}$ is a highly suitable cropping system for the plains of northern China. The trend was maintained in the experimental conditions of this experiment, in the 2012/13 and 2013/14 crop seasons.

However, linear regressions highlighting the $0.25 \mathrm{~m}$ spacing between rows of soybeans in Arapoti (PR-Brazil), diverge from Bell et al. [11]. At two densities in the 2012 and 2013 (Arkansas-USA) crops, the authors state that the best yields were reached $0.45 \mathrm{~m}$ row spacing.

When investigating the agronomic performance of soybean, Rosa et al. [12] asserted that the spacing increase increased the final population and height of the plant in the 2011/12 and 2012/13 harvests in Ponta Porã (MT-Brazil); Contrasting with the trends obtained in this experiment. However, with a confidence level greater than $95 \%$ probability, the tendency is confirmed that increasing spacing reduce pods per plant, grains per pod and productivity; Corroborating 


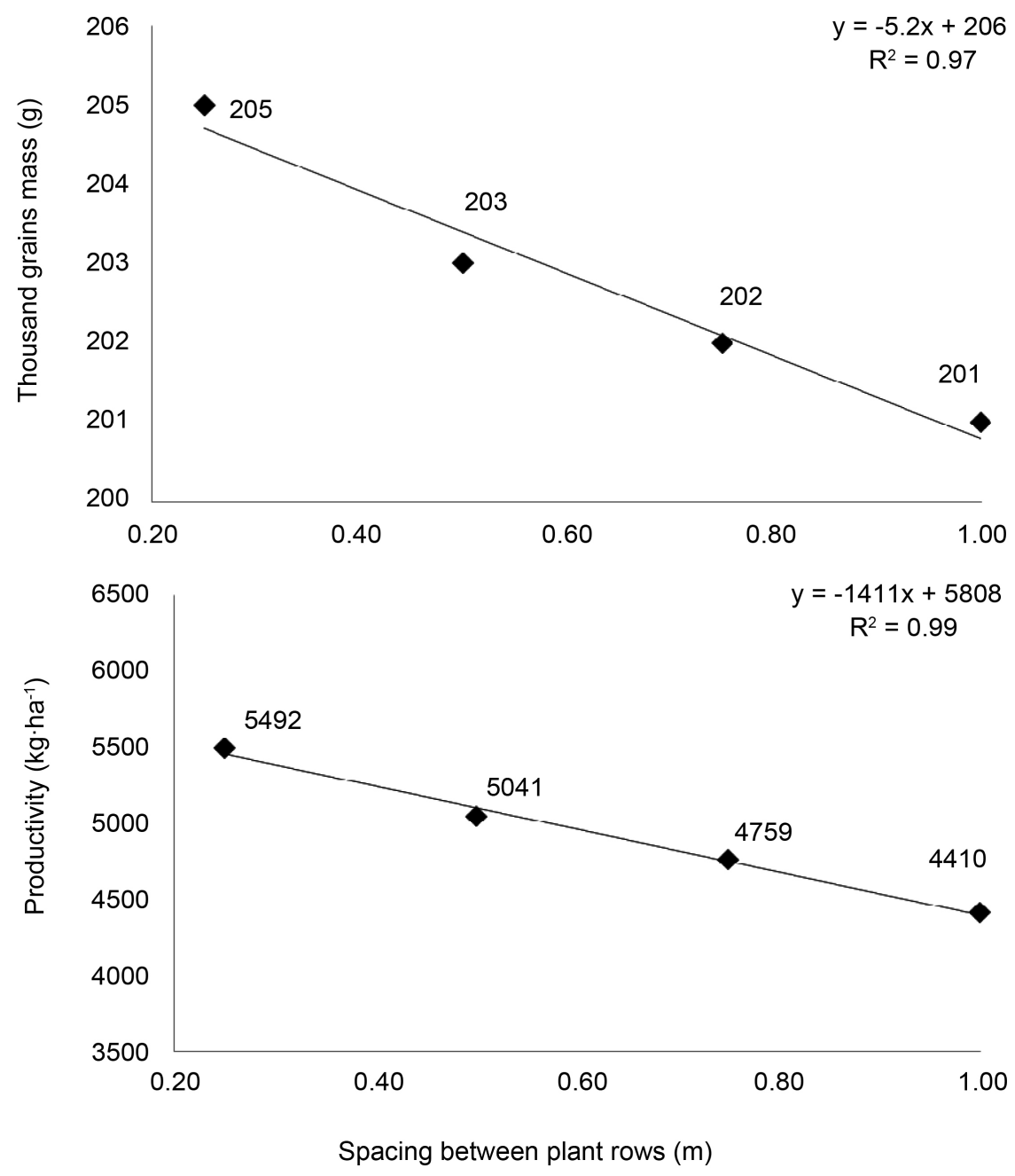

Figure 6. Components of soybean yield (Glycine max), cultivar BMX Apollo RR ${ }^{\circledR}$, seeded with different row spacings on 12/12/2013, Mutuca farm (Arapoti-PR, Brazil).

with the values raised at Mutuca farm.

In the western part of the state of Paraná-Brazil, Silva et al. [13] evaluated the behavior of two cultivars, in the 2013-14 crop, with four densities and two spacing $(0.25$ and $0.50 \mathrm{~m})$. The authors assure that the spacing of $0.25 \mathrm{~m}$ presented the best yields in most interactions between treatments, with a similar trend occurring in this experiment; in the mesoregion of central eastern Paraná.

\section{Conclusion}

We concluded that the reduction in row spacing significantly increased the variables: plant height, pods per plant, grains per pod, mass of one thousand grains and productivity. Therefore, under these experimental conditions, we recommend the soybean cultivation with spacing between rows of $0.25 \mathrm{~m}$.

\section{References}

[1] Cunha, R.C. and Espíndola, C.J. (2015) La récente dinamique geoeconomique de la 
chaine de production de soja au Brésil et dans le monde. Geotextos, 11, 217-238.

[2] WeirichNeto, P.H., Fornari, A.J., Bauer, F.C., Justino, A. and Garcia, L.C. (2013) Fungicide Application Using a Trailing Boom in Soybean fields. Engenharia Agrícola, 33, 876-882. https://doi.org/10.1590/S0100-69162013000400026

[3] Aulakh, J.S. and Jhala, A.J. (2015) Comparison of Glufosinate-Based Herbicide Programs for Broad-Spectrum Weed Control in Glufosinate-Resistant Soybean. Weed Technology, 29, 419-430. https://doi.org/10.1614/WT-D-15-00014.1

[4] Balbinot Jr., A.A., Procópio, S.O., Debiasi, H., Franchini, J.C. and Panison, F. (2015) Sowing in Crossed Rows in Soybean Cultivars with Determinate Growth Habit. Semina: Ciências Agrárias, 36, 1215-1226.

[5] Hartman, G.L., Pawlowski, M.L., Herman, T.K. and Eastburn, D. (2016) Organically Grown Soybean Production in the USA: Constraints and Management of Pathogens and Insect Pestss. Agronomy, 6, 1-18. https://doi.org/10.3390/agronomy6010016

[6] Koester, R.P., Nohl, B.M., Diers, B.W. and Ainsworth, E.A. (2016) Has Photosynthetic Capacity Increased with 80 Years of Soybean Breeding? An Examination of Historical Soybean Cultivars. Plant, Cell \& Environment, 39, 1058-1067. https://doi.org/10.1111/pce.12675

[7] Kumagai, E., Aoki, N., Masuya, Y. and Shimono, H. (2015) Phenotypic Plasticity Conditions the Response of Soybean Seed Yield to Elevated Atmospheric $\mathrm{CO}_{2}$ Concentration. Plant Physiology, 169, 2021-2029.

[8] Thompson, N.M., Larson, J.A., Lambert, D.M., Roberts, R.K., Mengistu, A., Bellaloui, N. and Walker, E.R. (2015) Mid-South Soybean Yield and Net Return as Affected by Plant Population and Row Spacing. Agronomy Journal, 107, 979-989. https://doi.org/10.2134/agronj14.0453

[9] Worku, M. and Astatkie, T. (2015) Effects of Row Spacing on Productivity and Nodulation of Two Soybean Varieties under Hot Sub-Moist Tropical Conditions in South-Western Ethiopia. Journal of Agriculture and Rural Development in the Tropics and Subtropics, 116, 99-106.

[10] Zhou, X.B., Chen, Y.H. and Ouyang, Z. (2015) Spacing between Rows: Effects on Water-Use Efficiency of Double-Cropped Wheat and Soybean. Journal of Agricultural Science, 153, 90-101. https://doi.org/10.1017/S0021859613000890

[11] Bell, H.D., Norsworthy, J.K., Scott, R.C. and Popp, M. (2015) Effect of Row Spacing, Seeding Rate, and Herbicide Program in Glufosinate Resistant Soybean on Palmer Amaranth Management. Weed Technology, 29, 390-404. https://doi.org/10.1614/WT-D-14-00156.1

[12] Rosa, C.B.C.J., Marchetti, M.E., Serra, A.P., Souza, L.C.F., Ensinas, S.C., Silva, E.R. and Jesus, M.V. (2016) Soybean Agronomic Performance in Narrow and Wide Row Spacing Associated with NPK Fertilizer under No-Tillage. African Journal of Agricultural Research, 11, 2947-2956. https://doi.org/10.5897/AJAR2016.11388

[13] Silva, I.F., Lorenzetti, E., Silva, S.F., Vezzaro, T., Hirsch, O., Nimet, M.S. and Alves Neto, A.J. (2016) Soybean Yield and Productivity Components According to Spacing and Population Density. African Journal of Agricultural Research, 11, 3532-3536. https://doi.org/10.5897/AJAR2016.11472 